\title{
Novel pathways of antigen presentation for the maintenance of memory
}

\author{
David Gray, Marie Kosco, and Brigltta Stockinger \\ Basel Institute for Immunology, Grenzacherstrasse 487, Postfach $\mathrm{CH} 4005$, Basel, Switzerland
}

Key words: follicular dendritic cells, memory B cells, memory T cells, germinal centers, MHC class $\|$, antigen transfer

\begin{abstract}
Follicular dendritic cells (FDC) store native antigen for long perlods In Iymphoid follicles and so provide a source of continued stimulation for specific B cells. The expression of MHC class II by FDC suggested they might act as antigen-presenting cells for MHC class II-restricted $T$ cells. We show here, however, that the MHC class II molecules found on their surface are not synthesized by the FDC but are plcked up from surrounding B cells in germinal centres. Although FDC by themselves cannot present native antigen to T cells, acquired MHC class II-peptlde complexes can be recognized by $T$ cells. The true physlological role of FDC seems to be as long-term antigen depots. We demonstrate that antigen localized onto FDC In vivo can be retrieved by antigen-specific $B$ cells, which in turn process and present it to $T$ cells. These presentation pathways are llkely to be crucial in both the maintenance of long-term immune responses and the continued survival of memory cells.
\end{abstract}

\section{Introduction}

The survival of memory B lymphocytes over long periods seems to require the continued presence of antigen (1). While this may occur via recurrent infection with the same or similar organisms $(2,3)$, there are specialized cells within secondary lymphoid organs that can store antigens for long periods $(4,5)$. These cells are follicular dendritic cells (FDC) that form a structural network within $\mathrm{B}$ cell follicles. During antibody responses, antigen antibody complexes are deposited via $\mathrm{Fc}(6)$ or $\mathrm{C} 3(7)$ receptors on the surface of $\operatorname{FDC}(8,9)$. The immediate consequence of this deposition is the formation of germinal centers, foci of rapidly proliferating $B$ cells that represent the clonal expansion of memory $B$ cells $(10,11)$. The germinal center reaction, however, is transient but FDC carrying intact antigen on their surface persist for long periods $(4,5)$. As long-term stores of antigen, it seems likely that they play a crucial role both in the maintenance of long-term antibody responses (12) and the continued survival of memory $B$ cells (1).

Data now emerging $(13,14 ; D$. Gray and $P$. Matzinger, submitted for publication) suggest that memory $T$ cells, as well as $B$ cells, depend upon periodic antigen stimulation for their longterm survival. The depots of antigen on FDC would be prime candidates as the source of this stimulation. However, it is not clear whether FDC could present this antigen directly to T cells or whether an intermediate antigen-processing $B$ cell is required.
Firstly, FDC are restricted to B cell follicles, areas that contain only small and possibly selected subsets of $T$ cells $(15-17)$. Secondly, current knowledge of antigen handling by FDC would indicate that they do not process antigen. Paradoxically, although they express MHC class II on the surface $(18,19)$, a prerequisite for antigen presentation, ultrastructural studies have shown that antigens are not internalized $(20,21)$.

In this report we investigate the functional capacity of FDC as antigen-presenting cells to both $T$ and $B$ cells. We show that while $B$ cells recognize antigen stored on FDC directly, a unique pathway of antigen transfer from FDC to $B$ cells allows processing and presentation to $T$ cells. This provides a means by which both memory $B$ cells and memory T cells receive persistent stimulation.

\section{Methods}

Animals

$\mathrm{BALB} / \mathrm{c}, \mathrm{CBA} / \mathrm{J}, \mathrm{C} 3 \mathrm{H}$, and $\mathrm{C} 57 \mathrm{BL} / 6$ mice were purchased from Iffa-Credo (Lyon, France). B10.D2, (CBA $\times B A L B / C) F_{1}$, and $(\mathrm{C} 3 \mathrm{H} \times \mathrm{DBA} / 2) \mathrm{F}_{1}$ mice were bred and maintained at the Basel Institute for Immunology breeding facility, Kaiseraugst. Sma58 transgenic (22) mice were kindly provided by Dr Diane Mathis (CNRS-INSERM, Strasbourg, France). 


\section{Bone marrow chimeras}

Two types of chimeras were used in this study. Firstly, to study antigen presentation by FDC to T cells we constructed parent $\rightarrow F_{1}$ chimeras; these were termed FDC/bone marrow chimeras. Secondly, to study the origin of MHC class If on the FDC surface we used fully allogeneic bone marrow chimeras. Both types of chimeras are described in detail below.

(i) FDC/Bone marrow chimeras were constructed in the following

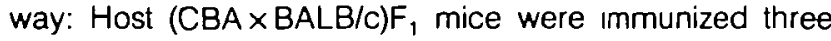
tımes, 2 weeks apart, twice with $250 \mu \mathrm{g}$ alum-precıpitated dinitrophenylated ovalbumin (DNP-OVA) płus $5 \times 10^{8}$ killed Bordetella pertussis above each footpad, and finally with 250 $\mu \mathrm{g}$ soluble DNP-OVA. Ovalbumin was fraction $\vee$ (Sigma Chemical Co., St. Louis, MO) and was DNP-labeled (substitution ratio 9:1) as described previousty (23). Three days after the final boost, the mice were lethally irradiated (950 cGy from a ${ }^{137} \mathrm{Cs} \gamma$ source; Atomic Energy Canada Ltd, Ottawa) and reconstituted with $2 \times 10^{7}$ ant-Thy1.2 (6.68 McAb; 24) plus complement-treated bone marrow cells from CBA mice Five weeks later reconstitution was assessed in tissue sections and cell suspensions from lymph nodes using immunofluorescence staining with the following antibodies: 14.8 (anti-B220, B cells; 25), F4/80 (anti-macrophage; 26), 4C11 (anti-FDC; M. Kosco and D. Gray, manuscript in preparation), 21.460 (antiH-2D d.b, host class I; a gift from Dr G. J. Hâmmerıng, Department of Immunology, DKFZ, Heidelberg), MK-D6 (anti-I-Ad, host class II; 27), and 14.4.4 (anti-l-Ek,d host and donor class II; 28). Staining is described in detail in the next section. Two days before the popliteal, brachial, and axillary lymph nodes were taken, mice were given 600 cGy irradiation.

(ii) Allogeneic bone chımeras were constructed as follows: C57BL/6 mice were lethally irradiated (950 cGy) and reconstituted with $2 \times 10^{7} \mathrm{~T}$ cell-depleted bone marrow cells from B10.D2 donors $\left(\mathrm{H}-2^{d}-\mathrm{H}-2^{\mathrm{b}}\right)$. Three weeks after reconstitution, chimeras were immunized in the footpad to generate germinal centers. Antibodies used for staining of tissue sections were: 14.4.4-biotin (antl-donor MHC class II, 28) and $\mathrm{R} 1.21 .2$ (anti-H2b host MHC class I; obtained from Dr G. J. Håmmerling, Department of Immunology, DKFZ, Heidelberg).

\section{Immunohistology}

Lymphoid organs were frozen in liquid nitrogen and mounted for cryostat sectionıng. Four micron sections were dried and acetone-fixed, and then co-incubated with the requisite first stage antibodies listed in other sections. First stage antibodies were a combination of mouse monoclonal antibodies that were biotinlabeled and rat monoclonal antibodies. These were revealed by co-incubation with streptavidin-Texas red (Southern Biotechnology Associates, Birmingham, $\mathrm{AL}$ ) and polyclonal rat anti-mouse IgG conjugated to fluorescein isothiocyanate (FITC) (Jackson Immuno Research Labs, Hamburg, FRG). Slides were viewed on a Zeiss Axiophot fluorescence microscope using $580-585 \mathrm{~nm}$ and $450-490 \mathrm{~nm}$ filters for Texas red and FITC respectively. Some sections were analyzed on a BıRad 600 Scanning Laser Conlocal Microscope, scanning at $0.5 \mu \mathrm{m}$ levels.

\section{FDC isolation}

FDC were isolated using a procedure that is essentially the same as that described by Schnizlein et al. (29). This consists of enzyme digestion of lymph nodes followed by densty gradient centrifugation. Cells harvested from the top of the $1.063 \mathrm{~g} / \mathrm{ml}$ density BSA (Bovine Serum Albumin, Path-o-cyte, Elkhart, IN) were incubated on tissue culture plates for $2 \mathrm{~h}$ at $37^{\circ} \mathrm{C}$ to deplete macrophages and lymphord dendritic cells. Because FDC cluster readily with $B$ cells during isolation (30), we reduced the number of $B$ cells contaminating the FDC preparations by irradiating ( $600 \mathrm{cGy}$ ) the mice 2 days pror to use.

\section{Antigen presentation by FDC}

FDC-containing cell suspensions from parent $\rightarrow F_{1}$ bone marrow chimeras described previously were plated in roundbottomed 96-well plates (Costar) in Iscove's modified Dulbecco medium supplemented with $10 \%$ FCS, $5 \times 10^{-5} \mathrm{M}$ mercaptoethanol, $2 \times 10^{-3} \mathrm{M}$ L-glutamine, and $100 \mu \mathrm{g} / \mathrm{ml}$ gentamycin. In order that the $T$ cell hybrid could come into close contact with the FDC, we reduced $B$ cell numbers in the cell preparations by irradiation ( $600 \mathrm{cGy}$ ) of the mice 2 days prior to killing. Serıal dilutions of FDC starting from $5 \times 10^{4}$ cells/well were irradiated ( $3200 \mathrm{cGy})$ and incubated with the T cell hybrid 4E12 $\left(5 \times 10^{4} /\right.$ well). This hybrid was generated by fusion of a clone derived from a B10.D2/0 mouse immunized with OVA (grade V. Sigma) with the T lymphoma BW 5147. $4 \mathrm{E} 12$ recognizes antigen in the context of I-Ad and is stımulated by antigen doses $<1 \mu \mathrm{g} / \mathrm{ml}$.

Transfer of MHC class / molecules from B cells to FDC in vitro $B$ cells were prepared from suspensions of lymph node and spleen from BALB/C $\left(\mathrm{H}-2^{d}\right)$ or C57BL/6 $\left(\mathrm{H}-2^{b}\right)$ mice by depletion with anti-Thy 1.2 and complement. B cells were stimulated with LPS (100 $\mu \mathrm{g} / \mathrm{ml}$ : Salmonella typhosa 0901; Difco Laboratories, Detroit, MI) plus $19 \% \quad \mathrm{~L}-4$ contaıning supernatant (31) at $2 \times 10^{-6} / \mathrm{ml}$ in 24-well costar plates. After $48 \mathrm{~h}$, supernatants were harvested and incubated with FDC from C57BL6 $\left(\mathrm{H}-2^{\mathrm{b}}\right)$ mice together with a defined OVA peptide $(323-339: 0.5 \mu \mathrm{M})$ which is recognized in the context of $1 . A d$ by the OVA-specific T cell hybrid 3DO-548 (32). Eighteen hours later the FDC were irradiated and responder $T$ cells added $\left(5 \times 10^{4} /\right.$ well). T cell activation was measured by interleukin 2 (IL-2) release after a further $24 \mathrm{~h}$ of culture. One hundred microliters of supernatants were transferred to fresh microtiter plates, together with $5 \times 10^{3}$ indicator cells/well (IL-2 dependent T cell line, CTLL). After another $24 \mathrm{~h}$ culture period, $1 \mu \mathrm{Ci} /$ well $[3 \mathrm{H}]$ thymidine was added and incorporation of thymidine was assessed $6 \mathrm{~h}$ later in a liquid scintillation counter.

\section{Antigen transfer from FDC}

In this assay we are asking if antıgen localized on the surface of an FDC in vivo can be transferred to an allogenelc $B$ cell for subsequent processing and presentation to a T cell hybrid. CBA $\left(\mathrm{H}-2^{\mathrm{k}}\right)$ mice were immunized twice with $250 \mu \mathrm{g}$ of alumprecipitated DNP.OVA + B. pertussis and once with $250 \mu \mathrm{g}$ soluble antigen above four foot pads. Four days later, FDC preparations were made. DNP-specific and keyhole limpet hemocyanin (KLH)-specific $B$ cells were prepared from lymph nodes of BALB/C $(\mathrm{H}-20)$ mice immunized $7-10$ days previously above each footpad with $250 \mu \mathrm{g}$ alum-precipitated DNP.KLH or $\mathrm{KLH}$ plus $B$. pertussis by depletion of T cells with anti-Thy $1+$ complement treatment. FDC were serially diluted from $5 \times 10^{4}$ cells/well. B cells were added at $1 \times 105 /$ well in 96-well roundbottomed culture plates (Costar), and FDC and $B$ cells were then 
incubated for $4 \mathrm{~h}$ at $37^{\circ} \mathrm{C}$ prior to irradiation with $3200 \mathrm{cGy}$ and addition of the $\mathrm{T}$ cell hybrid, 4E12, $(5 \times 104 /$ well). In some experiments we assayed the transfer of DNP-KLH, localized in vivo onto $F D C$ to DNP-specific $B$ cells and subsequent processing and presentation to a $\mathrm{KLH}$-specific T cell hybrid, $10 \mathrm{H}$ / A.H. This T cell hybrid was derived by fusing T cell clone $10 \mathrm{H} / \mathrm{A}$ (33) (kindly provided by $\mathrm{Dr}$ Peter Erb, Department of Microbiology, University of Basel) with the T cell lymphoma, BW5147. T cell activation was measured as described in the previous section.

\section{Results}

\section{Antigen presentation by FDC}

A technical problem encountered when testing the capacity of FDC to process and present antigen is their close contact with $B$ cells, which are very efficient antigen-presenting cells. To circumvent antigen presentation by contaminating $B$ cells, we took advantage of the fact that FDC are not derived from bone marrow cells (34) and constructed parent $-F_{1}$ chimeras in which only non-hemopoietıc cells such as FDC carry host $\mathrm{H}-2$. $\mathrm{CBA} \times \mathrm{BALB} / \mathrm{C}\left(\mathrm{H}-2^{\mathrm{k}} \times \mathrm{H}-2^{\circ}\right)$ hosts recelved three s.c. injections of DNP-OVA at weekly intervals before they were lethally irradiated and reconstituted with CBA bone marrow. After reconstitution, T cells, $B$ cells, and myeloid cells were of donor $\left(\mathrm{H}-2^{k}\right)$ orıgin whereas FDC remained of host orıgın (data not shown). We then asked if FDC prepared from the lymph nodes of these animals would present OVA directly to the I-Ad. restricted, OVA-specific T cell hybrid, 4E12.

In three experiments FDC failed to activate the T cell hybrid, even when exogenous antigen (DNP.OVA) was added to the cultures. Due to the essentially negative result, these data are not shown, while the experimental system is illustrated in Fig. 1. Immunohistological staining of lymph node sections from these chimeras unexpectedly showed that there was no host I-Ad associated with FDC, thus providing a rational explanation for the failure of antıgen presentatıon.

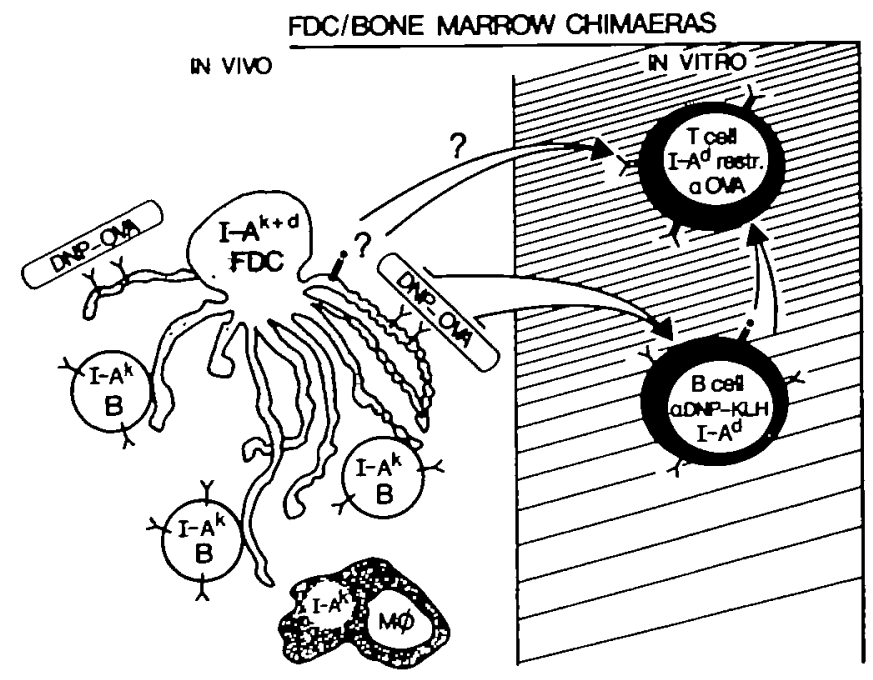

Fig. 1. Schematic diagram of the functional test of antigen processing and presentation by FDC.

\section{MHC class I/ expression by FDC}

The lack of expression of MHC class II by FDC in these chimeras conflicted with the published data $(18,19)$. We therefore investigated class II expression by FDC further. A convenient toot for these studies was a transgenic mouse line developed by D. Mathis and colleagues (22). Sma58 mice were derived by injection of an $1-E_{\alpha}$ construct into a recipient strain that has slent $\mathrm{I}-\mathrm{E}_{a}$ genes due to a deletion in the promoter region [(C57BL6 6 SJL)F2] Deletions in the ' $\mathrm{B}$ cell control' region $1-2$ $\mathrm{kb}$ upstream of the $E_{\alpha}$ construct result in aberrant expression in $B$ cell populations, such that peripheral, recirculating (resting) $B$ cells express no I-E while B cells in germinal centers do. The expression of the transgene in myeloid cells (macrophages and dendritic cells/interdigitating cells) is normal (22). This allowed us to study MHC class II expression on FDC in the absence of expression on $\mathrm{B}$ cells. It was also imperative for these studies to have a reliable marker for FDC. We have recently obtained a monoclonal antibody, $4 \mathrm{C} 11$, rased by immunizıng rats with mouse FDC preparations; while this will be described elsewhere (M. Kosco and D. Gray, manuscript in preparation), it can be seen from Fig. 2(a) that it is specific for FDC in lymphoid (B cell) follicles and recognizes nothing outside these structures. Figure 2(a) shows that in resting, primary follicles of spleen and lymph nodes of transgenic mice where the $B$ cells express no I-E, the FDC are also negative In contrast, when the $B$ cells up-regulate the transgene in an antıgen-driven germınal center, the FDC also become l-E-positive (Fig. 2b).

There are two possibilities that would explain this result. Either FDC do not synthesize I-E themselves, but rather pick it up from surrounding $B$ cells, or they up-regulate I-E in the same manner as germinal center $B$ cells. To distinguish these two possiblties, we set up allogeneic bone marrow chimeras [B10.D2 $\left(\mathrm{H}-2^{\circ}\right)-$ C57BL/6 $\left(\mathrm{H}-2^{\mathrm{b}}\right)$ ]. Figure 2(c) shows the staining of lymph node sections of a chimera, 4 weeks after reconstitution, with antibodies that detect FDC (4C11) and host MHC class I. The complete overlap of staining is visualized by the yellow color (mix of red and green). Figure 2(d) shows stainıng of the same tissue with $4 C 11$ and an antibody to detect donor $1-A^{d}$. Again, there is a complete overlap of this stainıng pattern. Figure 2(e) shows double staining for host class I and donor class II on the same section analyzed by confocal microscopy. The staining patterns we observe support the conclusion that MHC class II on FDC is picked up from B cells. However, immunofluorescence staining of tissue sections does not allow us to state unequivocally that the $4 \mathrm{C} 11$ epitope and class II are actually expressed on the same membrane. To further substantiate this hypothess, we attempted to detect transferred class II on the FDC in vitro.

\section{FDC pick up MHC class II shed by $B$ cells}

Rather than trying to detect donor MHC class II on isolated FDC from the allogeneic chimeras described in the previous section, we attempted to detect absorbed class II using a functional assay. The up-regulation and shedding of class II by B cells as it occurs in germinal centers can be mımicked in vitro by stimulation with lipopolysaccharide together with IL-4 (35). Overnight we incubated supernates from stimulated $\mathrm{H} \cdot 2^{\mathrm{d}} \mathrm{B}$ cells with FDC from $\mathrm{H}-2^{\mathrm{b}}$ mice and a defined ovalbumin peptide $(323-339)$ recognized by the $T$ cell hybrid, 3DO-548. Table 1 shows that $\mathrm{H}-2^{b}$ FDC were unable to present peptide to the $T$ cell hybrid. Upon incubation with supernatant from $\mathrm{H} \cdot 2^{\mathrm{d}}$ but not $\mathrm{H} \cdot 2^{\mathrm{b}}$ mice, 
144 Antigen presentation for long-term memory

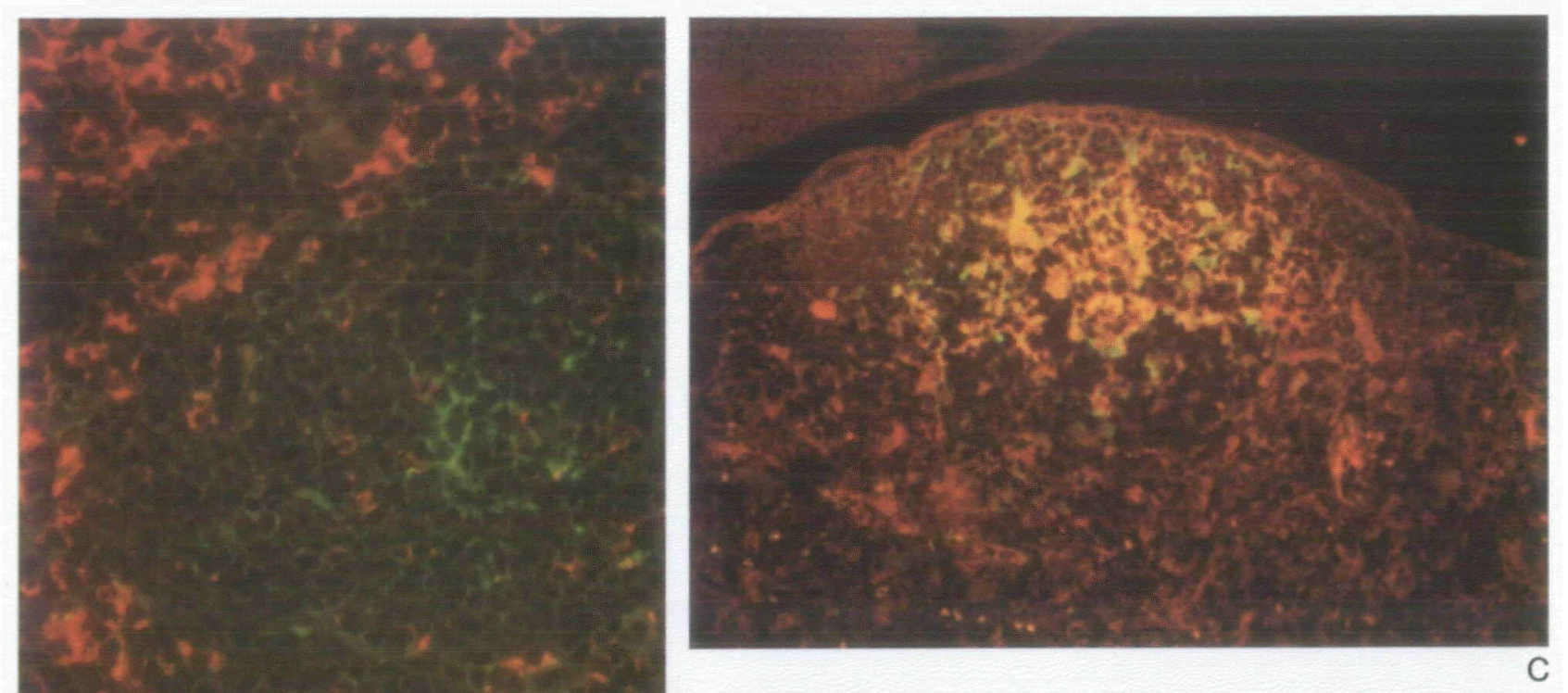

a
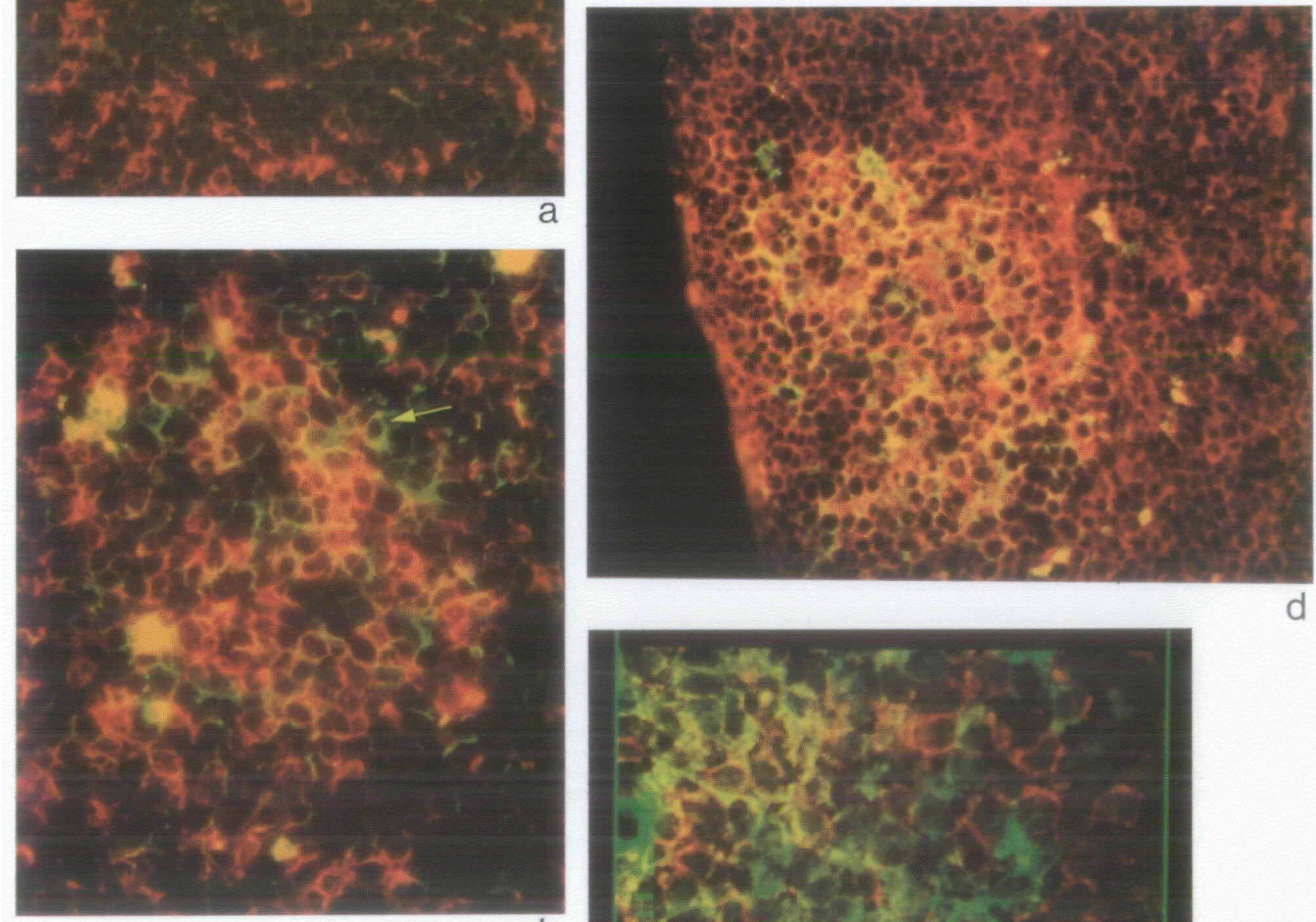

d

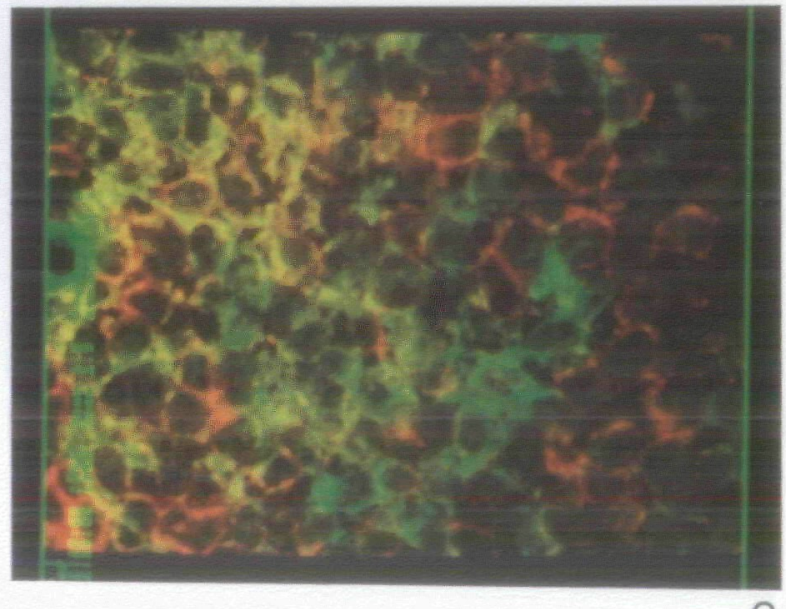


Table 1. FDC pick up MHC class II shed by B cells

\begin{tabular}{llll}
\hline APC & $\begin{array}{l}\text { Class II } \\
\text { source B cell } \\
\text { supernatant }\end{array}$ & Antibody added & $\begin{array}{l}\text { IL-2 production } \\
\text { by anti-OVA } \\
\text { T cell hybrid } \\
\text { (c.p.m.) }\end{array}$ \\
\hline FDC & H-2d conc. & - & 15.801 \\
H-2b & $1: 3$ & - & 5231 \\
& 1.9 & - & 870 \\
& conc & MK-D6 (antr-I-Ad) & 925 \\
& $H-2^{\text {b }}$ conc. & - & 571 \\
\hline
\end{tabular}

FDC could now activate the $T$ cell hybrid. This effect was dosedependent and inhibited by anti-I-Ad antibodies. The results clearly show that FDC are able to pick up MHC class II and can use them for direct presentation to $T$ cells.

\section{FDC can present but do not process antigen}

If one considers that MHC class II molecules are almost always occupied by peptides, the acquisition of such class II + peptide complexes from B cells might enable FDC to present directly to $T$ cells. We found that in one group of parent $\rightarrow F_{1}$ chimeras similar to those depicted in Fig. $1\left[\mathrm{C} 3 \mathrm{H}\left(\mathrm{H}-2^{\mathrm{k}}\right) \rightarrow \mathrm{C} 3 \mathrm{H} \times \mathrm{DBA} / 2\right.$ $\left.\left(\mathrm{H}-2^{k} \times H-2^{d}\right)\right]$, FDC obtained 5 weeks after reconstitution were able to activate the I-Ad-restricted anti-OVA T cell hybrid, 4E12 (Table 2, group A). Staining of lymph node sections from these chimeras showed that the only cells carrying host I-Ad were FDC (data not shown). Thus, class II originally picked up from host $B$ cells had persisted for 5 weeks on the FDC surface and was able to stimulate a $T$ cell hybrid. Addition of exogenous antigen to the FDC during culture did not increase the response (Table 2 , group A), consistent with the notion that FDC do not themselves process antigen.

\section{Antigen transfer from $F D C$ to $B$ cells}

Since FDC do not process antigen, $B$ cells would be crucial for providing antigen in a form suitable for $T$ cell recognition. Therefore, native antigen stored on FDC must be transferred to $B$ cells for processing. To show that such an antigen transfer is functionally possible, we localized antigen (hapten-carrier conjugate) onto FDC in vivo, made cell preparations enriched for FDC, and tested in vitro if the hapten-carrier conjugate could be picked up by hapten-specific B cells and presented to a carrier-specific $T$ cell hybrid. To circumvent the problem of antigen-presenting $B$ cells contaminating the FDC preparation we used allogeneic combinations of FDC and B cells. FDC donors ( $\mathrm{H}-2^{\mathrm{k}}$ mice) were immunized twice with DNP-OVA and then given $600 \mathrm{cGy}$ irradiation $48 \mathrm{~h}$ prior to set up in vitro. Irradiation reduces the number of $B$ cells in the FDC preparation as these tend to form clusters with FDC during isolation and prevent access of the antigen-presenting $B$ cells added in vitro. The $B$ cells added to the cultures came from $\mathrm{H}-2^{d}$ mice immunized with the hapten coupled to an unrelated carrier (DNP. hemocyanin, $K L H)$. The responding $T$ cell hybrid, $4 E 12$, recognizes OVA in the context of I-Ad.

Figure 3 shows that the combination of FDC bearing DNP-OVA immune complexes and B cells specific for DNP-KLH was capable of stimulating IL-2 secretion by the OVA-specific T cell hybrid without the requirement for any further addition of antigen to the culture. Neither FDC bearing inappropriate MHC class II nor $\mathrm{B}$ cells alone could activate the hybrid. DNP-OVA added to the culture was efficiently presented by DNP-KLH Immune B cells. The transfer of DNP-OVA from FDC to B cells was dependent upon the hapten specificity of their antigen receptor. Within the dose range shown, B cells from mice primed with KLH only did not pick up and present DNP-OVA from the FDC (Fig. 3).

Only antigen stored on FDC was available for B cell presentation. Macrophages and interdigitating cells isolated as adherent cells from DNP-OVA-immune $\mathrm{H} \cdot 2^{\mathrm{k}}$ mice did not function as antigen depots and no transfer to $\mathrm{H}-2^{\mathrm{d}} \mathrm{B}$ cells was observed in vitro (Table 2, group $B$ ). The passage of antigen from FDC to $B$ cells is not unique to DNP-OVA and the OVA-specific T cell hybrid, but can occur using a different antigen (DNP-KLH) and a different $T$ cell hybrid, 10H/A.H, specific for $K L H+1-A^{d}$ (Table 2, group C).

\section{Discussion}

The experiments described in this paper were designed to investigate the mechanisms of antigen handling in $B$ cell follicles. The antigen in these sites is of critical importance during at least two phases of the immune response. During the primary response (5-7 days after immunization) antigen - antibody complexes become deposited onto the surface of FDC, initiating the germinal center reaction that generates memory $B$ cells $(10,11)$. Later, in the established phase of antibody responses, the immune complex on FDC is likely to be a stimulus for continued serum antibody production $(12,36)$ and for the maintenance of memory B cells (1). Growing evidence that T cell memory is likewise dependent upon antigen persistence $(13,14,37 ; D$. Gray and P. Matzinger, manuscript submitted) led us to investigate how antigen localized on FDC would be accessible for the stimulation of $\mathrm{T}$ cells.

Flg. 2. MHC class II expression by follicular dendritic cells. (a) A primary B cell follicle in the spleen of a Sma58 transgenic mouse stained to show 1-Ek transgene expression (red) and FDC (green). FDC here do not express the transgene. (b) A germinal center in the spleen of a Sma58 mouse 7 days after immunization with alum-precipitated DNP-OVA. Double staining for I-Ek (red) and FDC (green) shows that there is extensive overtap (yellow): the arrow indicates an FDC that expresses 1- $E^{k}$ only on the dendritic processes that contact an 1-Ekpositive $B$ cell and not on those that do not. (c) The staining for class host I (red) and FDC (green) in a germinal center in a lymph node from an allogeneic bone marrow chimera 4 weeks after reconstitution. The yellow color (red/green overlap) shows the expression of both markers on FDC; it should be noted that the dendritic, reticular pattern is characteristic of FDC staining and not the ring-like staining of B cells. (d) The staining for donor class II (red) and FDC (green) in a germinal center from the same lymph node as in (c); note again the complete overlap of staining (yellow). (e) A picture of a germinal center from the chimeric mice showing host class I (green) an donor class II (red), obtained using a Biofad 600 scanning laser confocal microsocope, scanning at $0.5 \mu m$ levels through the section. 
Table 2.Transfer of antigen on FDC to antigen-specific B cells

\begin{tabular}{|c|c|c|c|c|c|c|c|}
\hline \multirow{2}{*}{$\begin{array}{l}\text { Responding } T \text { cell } \\
\text { hybrid }\end{array}$} & \multicolumn{4}{|c|}{ Antigen localization } & \multirow{2}{*}{$\begin{array}{l}\text { DNP-primed } \\
\text { B cells }(\mathrm{H}-2 \mathrm{~d}) \\
\text { added to } \\
\text { culture }\end{array}$} & \multirow{2}{*}{$\begin{array}{l}\text { Exogenous } \\
\text { antigen }\end{array}$} & \multirow{2}{*}{$\begin{array}{l}\text { IL-2 production } \\
{\left[{ }^{3} \mathrm{H}\right] \text { thymidine }} \\
\text { uptake (c.p.m.) }\end{array}$} \\
\hline & Cell type & Cell no & $\mathrm{H}-2$ & Antıgen & & & \\
\hline \multirow{4}{*}{$\begin{array}{cc}\text { Group A: } & 4 E 12 \\
& \left(O V A+1-A^{d}\right)\end{array}$} & ${ }^{n} \mathrm{FDC}$ & $10^{5}$ & $k+d$ & DNP-OVA & none & none & 11,836 \\
\hline & & $n$ & $"$ & "t & none & DNP-OVA & 13,147 \\
\hline & - & - & - & - & $10^{5}$ & none & 1190 \\
\hline & - & - & - & - & $10^{5}$ & DNP-OVA & 41,397 \\
\hline \multirow{4}{*}{$\begin{array}{lc}\text { Group B: } & 4 E 12 \\
\left(\mathrm{OVA}^{\prime}+\mathrm{I}^{d}\right)\end{array}$} & $M \emptyset$ & $5 \times 10^{4}$ & $k$ & DNP-OVA & none & none & 329 \\
\hline & $"$ & $n$ & $n$ & " & none & DNP-OVA & 442 \\
\hline & $n$ & H & $n$ & $"$ & $10^{5}$ & none & 228 \\
\hline & $"$ & $n$ & $"$ & $"$ & $10^{5}$ & DNP-OVA & 51.398 \\
\hline \multirow{10}{*}{ Group C: $\begin{aligned} & 10 H / A \cdot H \\
&\left(K L H+1-A^{d}\right)\end{aligned}$} & FDC & $5 \times 10^{4}$ & k & DNP-KLH & $10^{5}$ & none & 11,365 \\
\hline & $"$ & $25 \times 10^{4}$ & $n$ & " & $n$ & $"$ & 10,191 \\
\hline & $"$ & $1.25 \times 10^{4}$ & $n$ & $"$ & $n$ & $n$ & 7193 \\
\hline & " & $0.6 \times 10^{4}$ & $"$ & ${ }^{\prime \prime}$ & $n$ & $"$ & 3921 \\
\hline & $"$ & $5 \times 10^{4}$ & 7 & $n$ & $n$ & DNP-KLH & 14,751 \\
\hline & $"$ & $2.5 \times 10^{4}$ & $n$ & $"$ & $n$ & $"$ & 14,163 \\
\hline & $"$ & $1.25 \times 10^{4}$ & $"$ & $"$ & $"$ & $"$ & 15,610 \\
\hline & " & $0.6 \times 10^{4}$ & " & ${ }^{n}$ & ${ }^{n}$ & $"$ & 16,815 \\
\hline & FDC & $5 \times 10^{4}$ & " & $"$ & $n$ & none & 587 \\
\hline & FDC & $5 \times 10^{4}$ & 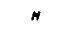 & $"$ & $n$ & DNP-KLH & 1086 \\
\hline
\end{tabular}

Group $A \cdot$ the presentation to $T$ cells of OVA on the surface of FDC from chimeras simitar to those described in Fig. $1,\left(\mathrm{C} 3 \mathrm{H}\left(\mathrm{H}-2^{\mathrm{k}}\right) \rightarrow(\mathrm{C} 3 \mathrm{H} \times \mathrm{DBA} 2) \mathrm{F}_{1}\right.$ $\left(\mathrm{H}-2^{k} \times H-2^{9}\right)$. Lymph nodes in these mice exhibited class II of host origin (I-Ad, detected by MK-D6) associated with FDC; group B. adherent cells (macrophages or lymphoid dendritic cells) from the donors of FDC in the antigen transfer experiment depicted in Fig. 3 do not carry antigen that can be passed to $B$ cells Adherent cells were cells that stuck to plastic Petri dishes during a $2 \mathrm{~h}$ incubation at $37^{\circ} \mathrm{C}$ of the FDC-ennched fraction taken from the BSA gradient; group C. in vitro transfer of DNP-KLH localized onto FDC in vivo to DNP-specific B cells and subsequent processing and presentation to a KLH-specific T cell hybnd, 10H/A.H

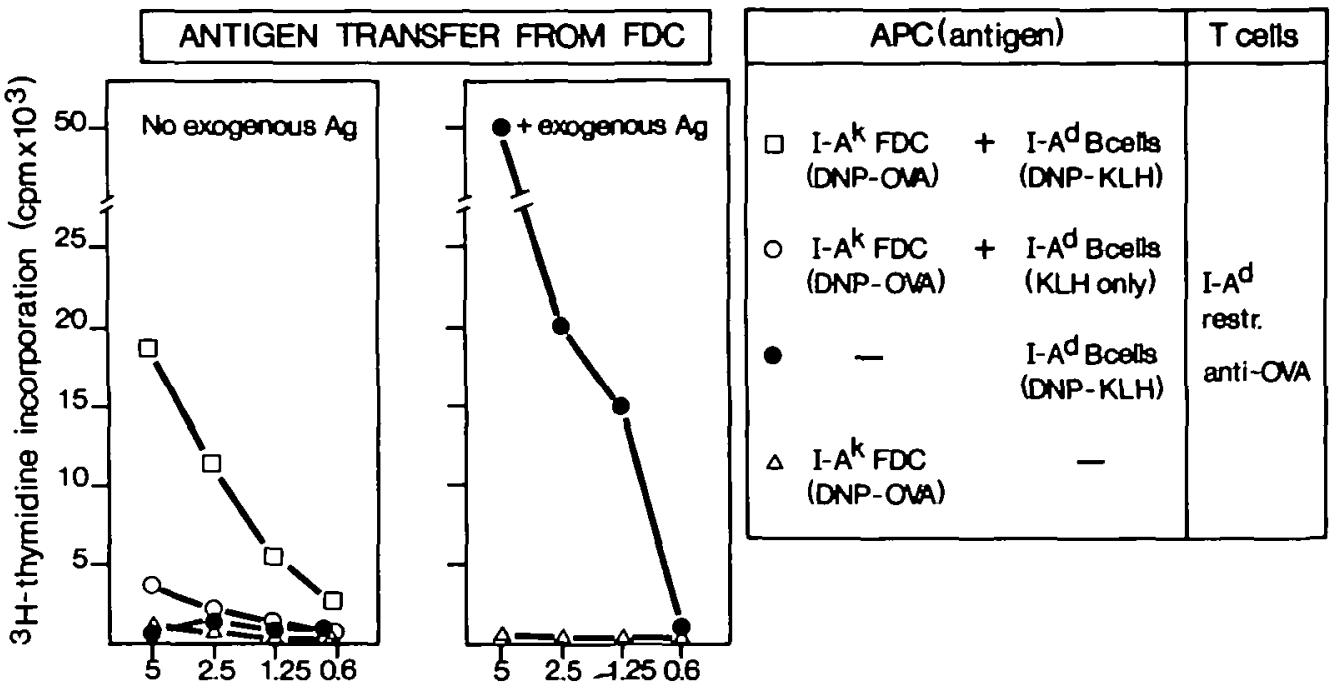

Number of cells added per well $\left(\times 10^{4}\right)$

Fig. 3. In vitro transfer of antigen localization onto FDC in vwo to specific B cells.

The experiments presented here show that the FDC that maintain antigen as an immune complex on their surface for periods of months $(4,5)$, and possibly years, are incapable of processing it and presenting it to $T$ cells. This agrees with electron microscope studies of Szakal and colleagues in that they observed no internalization of antigen by $\operatorname{FDC}(20,21)$. While we would have liked to purify FDC to the extent that we could ask directly if they would process and present, this proved impossible due to the property of FDC to form clusters with contaminating $B$ cells, which would serve as potent antigen-presenting cells. This problem was circumvented by the construction of parent into $F_{1}$ bone marrow chimeras in which the only cell that could potentially present directly to the I-Ad-restricted anti-OVA T cell hybrid was an FDC. The results of the experiments were negative with one notable exception. As a prerequisite for antigen presentation, FDC in these chimeras required expression of the 
relevant, host-type class II MHC. Analysis of the parent $-F_{1}$ chimeras revealed that FDC did not express host class II, with the exception of one group of mice. FDC in this exceptional group stimulated $T$ cells directly. Addition of antigen in culture did not increase the response further, which is in agreement with the observation that FDC do not process antigen.

Paradoxically, the immediate reason for the inability of FDC in these chimeras to present was the lack of appropriate $\mathrm{MHC}$ class II molecules on their surface, a finding in contradiction with previous reports in the literature $(18,19)$. The mystery was solved by the finding that $\mathrm{MHC}$ class II on the surface of an FDC is not synthesized by the cell itself but is acquired from surrounding $B$ cells. In line with this observation, in Sma58 transgenic mice which have a defect in I-E expression in B cells, the FDC are also negative for I-E except those in germinal centers where $B$ cells up-regulate and express the $\mathrm{I}-\mathrm{E}$ transgene. Co-expression of host class I and donor class II on FDC from allogeneic bone marrow chimeras indicates that MHC class II molecules normally seen on the surface of FDC are in fact derived from B cells. While we cannot resolve unequivocally, with light microscopy on tissue sections, whether two molecules are localized on the same membrane, we have demonstrated that MHC class II shed from the surface of B cells during culture is absorbed by FDC and can stımulate an appropriately restricted $T$ cell hybrid.

In germınal centers in normal mice, activated $B$ cells increase their surface class II levels by 2 - to 3 -fold (38), a phenomenon that may result in the release of class II into the interstitial fluid. In this context, activated $B$ cells have been reported to shed class II into culture medium $(39,40)$. Whether the release is due to an active process or to cell death, of which there is ample in the germinal center (41), cannot be distinguished at present However, we do have prelıminary data that shedding of class II into tissue culture medium is related to the up-regulation following stimulation with IL-4 + LPS, while in cultures stimulated with LPS alone there is no evidence of shed class II.

Both the mechanism of uptake by FDC of shed class II and the physiological relevance of the process remain obscure. For the means of uptake, two mechanisms suggest themselves. Firstly, direct membrane fusion: previous studies (40) showed that the class II shed from activated B cells was associated with membrane lipid (the transfer of other molecules such as class I would be precluded). Secondly, there is evidence that MHC class II is closely associated in the B cell membrane with CD23 (low-affinity IgE FC receptor) (42). In a germinal center B cells lose CD23 expression (43) while FDC in active sites express high levels (43); it is possible that shed class II could associate with the CD23 on the FDC. As for the relevance of this process, it seems that FDC can stimulate T cells directly by presenting class II - peptide complexes picked up from B cells. An in vivo example of this is the exceptional set of parent $\rightarrow F_{1}$ chımeras which contained OVA-presenting FDC 5 weeks after irradiation and reconstitution (see Table 2, Group A). The class II - OVA peptide complexes on the surface of these cells were of host origin picked up from antigen-activated $B$ cells prior to irradiation. This in vivo observation can be mimicked in vitro by incubating FDC of inappropriate $\mathrm{H}-2$ haplotype with supernatant from stimulated $\mathrm{H}-2^{d} \mathrm{~B}$ cells. Considering that the transfer of antigen from FDC and subsequent processing by $B$ cells seems to be a highly efficient means of stimulating T cells, why should FDC present passively acquired class II - peptide complexes? The presenta-

tIon of antigen by FDC may be a means of optimizing the stimulation of $T$ cells during a phase of $B$ cell differentiation (i.e. in germinal centers) in which they lose surface membrane immunoglobulin $(44,45)$ and hence their capacity to take up antigen for processing and presentation.

At the moment, however, we believe that the major pathway for the presentation of antigen for the maintenance of $T$ and $B$ cell responses and $T$ and $B$ cell memory is the one proposed by Tew and co-workers ( $46-49)$, for which we provide experimental evidence in this paper. This involves the transfer of antigen from the surface of FDC to B cells for subsequent processing and presentation to $T$ cells, an interaction that would result in proliferative, differentiative, or merely survival signals for both the participants. Iccosome structures (46) on FDC dendritic processes have been proposed as the packets of antigen that are picked up by $B$ cells in the early phase of the germinal center reaction and, indeed, $B$ cells taken ex vivo from primed mice will present without addition of exogenous antigen to a $T$ cell hybrid (47). Here we demonstrate the whole process in vitro: FDC taken from primed mice can act as a source of unprocessed antigen only for specific B cells that in turn process and present to $T$ cells to close the loop of immune stimulation in germina centers.

In conclusion, we feel that we have demonstrated two unique antıgen presentatıon pathways, one of which may be important during the development of memory in a germinal center and the other crucial for the mantenance of secondary immune responses and the continued survival of both $B$ and $T$ memory cells.

\section{Acknowledgements}

We thank Rita Schmid, Barbara Hausmann, and Helena Skarvall for technical assistance, Drs Harald von Boehmer, Antonio Lanzavecchia, and Ron Palactos for critical reviews of the manuscnpt, and Nicole Schoepflin for preparing it. We are indebted to Dr Diane Mathis for the Sma58 transgenic mice and Dr Peter Erb for the 10H/A T cenl clone. The Basel Institute for Immunology was founded and is supported by F. Hoffmann-La Roche Lid, Basel, Switzerland

\section{Abbreviations}

DNP

FDC

FITC

IL-2

KLH

OVA

\section{References}

1 Gray, D. and Skarvall, H. 1988. B cell memory is short-lived in the absence of antigen. Nature 336:70.

2 Mims, C. A. 1987. Pathogenesis of Infectious Disease, 3rd edn. Academic Press, London.

3 Fazekas de St. Groth, S. and Webster, R. G. 1966. Disquisitions on original antigenic sn. I. Evidence in man. J. Exp. Med. 124:331.

4 Tew, J. G., Phipps, R. P., and Mandel, T. E. 1980. The follicular dendritic cell: long-term antigen retention during immunity. Immunol. Rev. 53.29

5 Tew, J. G. and Mandel, T. E. 1979. Prolonged antigen half-life in the lymphoid follicles of specifically immunized mice. Immunotogy 37:69.

6 Herd, Z. L. and Ada, G. L. 1969. Distribution of 125/-immunoglobulin subunits and antigen-antibody complexes in rat lymph nodes. Aust. J. Exp. Biol. Med. Sci. 47:73.

7 Papamichail, M., Guttierez, C., Embling, P., Johnson, P., 
Holborrow, E. S. and Pepys, M B. 1975. Complement dependence of localization of aggregated IgG in germinal centers. Scand. J. Immund. 4:343.

8 Nossal, G. J. V., Abbot, A., Mitchell, J., and Lummus, Z. 1968. Antigens in immunity XV. Ultrastructural features of antigen capture in primary and secondary lymphord follicles. J. Exp. Med. 127.277.

9 Humphrey, J. H. and Frank, M. M. 1967. Locafization of non-microbtal antigens in the draining lymph nodes of tolerant, normal and primed rabbits. Immunology 13:87.

10 Klaus, G. G. B. and Humphrey, J. H. 1977. The generation of memory cells. I. The role of $\mathrm{C} 3$ in the generation of mernory B cells. Immunotogy 33:31.

11 Coico, R. F., Bhogal, B. S., and Thorbecke, G. J. 1983. Relationship of germinal centers in lymphoid tissue to immunologic memory. VI. Transfer of $B$ cell memory with lymph node cells fractionated according to the receptors for peanut agglutinin. J. Immunol. 131:2254.

12 Tew, J. G., Phıpps, R. E., and Mandet, T. E. 1980. The mantenance and regulation of the humoral immune response: persisting antigen and the role of follicular antigen-binding dendritic cells as accessory cells. Immunol. Rev 53:175.

13 Gray, D. and Leanderson, T. 1990. Expansion, setection and maintenance of memory B cell clones. Curr. Topics Mrcrobiol. Immunol. 159:1

14 Gray. D. 1990 . Immunological memory: long-lived cells or long-lived antıgen? In Janeway, C. A., Sprent, J., and Secarz, E., eds, Immunogenicity, p. 219. Wiley-Liss Pubdications, New York.

15 Kroese, F. G. M. Wubbena, A. S., Jolıng, P., and Nieuwenhuis, P. 1985. T lymphocytes in rat lymphoid follicles are a subset of Thelper cells Adv Exp. Med. Bia. 186.443

16 Rouse, R. V., Ledbetter, J A., and Weissman, I. L 1982. Mouse lymph node germinal centers contain a selected subset of $T$ cells-the helper phenotype J. Immund. 128:2243.

17 Michie, S A and Rouse, R. V. 1988. Study of murine T cell migration using the Thy-1 allotypic marker. Transplantation 46.98

18 Gerdes, J, Stein, H., Mason, D. Y., and Ziegler, A. 1983. Human dendritic retrculum cells of lymphoid follicles' their antigenic profile and the identification as multunucleated giant cells. Virchows Arch. 42.161.

19 Kosco, M. H., Tew, J. G., and Szakal, A. K. 1986. Antugenic phenotyping of isolated and in situ rodent follicular dendrittc cells with emphasis on the ultrastructural demonstration of la antigens. Anat. Rec. 215:201.

20 Szakal, A. K. and Hanna, M. G. 1968. Ultrastructure of antigen localization and virus-like partcles in mouse spleen germinal centers. Exp. Mol. Pathot. 8:75.

21. Szakal, A. K., Gieringer, R. L., Kosco, M. H., and Tew, J. G. 1985. Isolated follicular dendritic cells: cytochemical antigen localization, Nomarski, SEM and TEM morphology. J. Immunol. 134:1349.

22 van Ewijk, W., Ron, Y., Monaco, J., Kappler, J., Marrack, P.. Le Meur, M., Gertinger, P., Durand, B., Benoist, C., and Mathis, D. 1988. Compartmentalization of MHC class II gene expression in iransgenic mice. Cell 53:357.

23 Gray, D., Chassoux, D., MacLennan, I. C. M., and Bazin, H. 1985. Selective depression of thymus-independent anti-DNP antibody responses inctuced by adult but not neonatal splenectomy. Clin. Exp. Immunot. 60:78.

24 Hămmerling. G., Lemke, H., Hămmerling, U., Hōhmann, C., Wallich, R., and Rajewsky, K. 1978. Monoclonal antibodies against murine cell surface antigens. Anti-H-2, anti-la and anti-T cell antibodies. Curr. Topics Microbiol. Immunol. 81.100.

25 Kincade, P. W., Lee, G., Watanabe, T., Sun, L., and Scheid, M. P. 1981. Antigens displayed on murine $B$ lymphocyte precursors. J. Immunal. 127:2262.

26 Austyn, J. M. and Gordon, S. 1981. F4/80, a monoctonal antibody directed specifically against the mouse macrophage. Eur. J. Immund. $11: 805$

27 Kappler, J. W., Skidmore, B., White, J., and Marrack, P. 1981. Antigen inducible, $\mathrm{H}-2$ restricted, interleukin-2-producing $\mathrm{T}$ cell hybridomas. Lack of independent antigen and $\mathrm{H} \cdot 2$ recognition. J. Exp. Med. 153:1198.
28 Ozato, K., Mayer, N., and Sachs, D. H. 1980. Hybridoma cell lines secreting monoclonal antibodies to mouse $\mathrm{H}-2$ and la antigens J. Immunod. 124.533.

29 Schnizleın, C. T., Kosco, M. H, Szakal, A. K, and Tew, J. G. 1985. Follicular dendritic cells in suspension: identification, enrichment and initial characterization indicating immune complex trapping and lack of adherence and phagocytic activty. J. Immunol. 134:1360.

$30 \mathrm{Kosco}, \mathrm{M}$. and Gray, D. 1990. Isolation of cells involved in the germinal center reaction germinal center $B$ cells and follicular dendritic cells. In Lefkovits, I. and Pernis, B., eds, Immunological Methods, Vol. IV, p. 280 . Academic Press, New York.

31 Karasuyama, H. and Melcher, F. 1988. Establishment of mouse cell lines which constitutively secrete large quantities of interleukin 2,3 . 4 or 5 , using modrfied cDNA expression vectors. Eur. J. Immund. 18:97

32 Kappler, J., Kubo, R, Haskins, K., White, J., and Marrack, P. 1983. The mouse T cell receptor: comparison of MHC-restricted receptors on two T cell hybridomas. Cell 34:727.

33 Erb, P., Grogg, D., Troxder, M., Kennedy, M., and Flun, M. 1990. $\mathrm{CD} 4+\mathrm{T}$ cell-mediated killing of MHC class II-positive antigen presentung cells. I. Characterization of target cell recognution by in vivo or in vitro activated killer T cells. J. Immunol. 144:790.

34 Humphrey, J H., Grennan, D., and Sundaram, V. 1984. The origin of follicular dendritic cells in the mouse and the mechanism of trapping immune complex on them. Eur. J. Immunol. 14:859.

35 Noelle, R. J., Kuziet, W. A., Maliszewski, C. R., McAdams, E., Vitetta, E. S., and Tucker, P. W 1986. Regulation of the expression of multuple class II genes in murine B cells by the B cell stimulatung factor-1 (BSF-1). J. Immunol. 137:1718.

36 Tew, J. G. and Mandel, T. E. 1978. The maintenance and regulation of serum antibody levets: evidence indicating a role for antigen retained in lymphad follicles. J. Immunot. 1201063.

37 Zinkernaget, R. M. 1990. Antr-viral T-cell memory? Curr. Topics Microbial. Immunat. 159:65.

38 Butcher, E. C., Rouse, R. V., Coffman, R. L., Nottenburg, C. N., Hardy, R R., and Wessman, I. L. 1982. Surface phenotype of Peyer's patch germinal center $B$ cells implications for the role of germinal centers in B cell differentiation. J. Immunot. 129.2698.

39 Emerson, S. and Cone, R. E. 1981. Regulation of murine B lymphocyle plasma membrane protein turnover and shedding. J Cell Physid 109:25.

40 Emerson, S. and Cone, R. E. 1981. I-Ak and H-2k antigens are shed as supra-molecular particles in association with membrane lipids. J. Immunot. 127:482

41 Lui, Y. -J., Joshua, J. E., Willıams, G. T., Smith, C. A., Gordon, J., and MacLennan, I. C. M 1989. Mechanism of antigen-driven sefection in germinal centers. Nature 342:929.

42 Bonnefoy, J. Y., Guillot, O., Spits, H., Blanchard, D., Ishızaka, K., and Banchereau, J. 1988. The low-affinity receptor for $\lg E(C D 23)$ on $B$ lymphocytes is spatially associated with HLA-DR antigens. $J$ Exp. Med. 167.57.

43 Gordon, J., Fores-Romo, L., Cairns, J. A., Millsum, M. J., Lane, P. J., Johnson, G. D., and MacLennan, I. C. M. 1989. CD23 a multifunctional receptor/ymphokine? Immunol. Today 10.153.

44 Stein, H., Gerdes, J., and Mason, D. Y. 1982. The normal and malignant germınal center. Clin. Haematot. 11:531.

45 MacLennan, I. C. M., Lui, Y. J., OAdfield, S., Zhang, J., and Lane, P. J. L. 1990. The evolution of B-cell clones. Curr. Toptcs Microbiol. Immunal. 159:37.

46 Szakal, A. K., Kosco, M. H., and Tew, J. G. 1988. A novet in vio follicular dendritic cell-dependent iccosome-mediated mechanism for delivery of antigen to antigen processing cells. J. Immunol. 140:341.

47 Kosco, M. H., Szakal, A. K., and Tew, J. G. 1988. In vivo obtained antigen presented by germinal center $B$ cells to $T$ cells in vitro. J. Immunol. 140:354.

48 Tew, J. G., Kosco, M. H., and Szakal, A. K. 1989 The alternative antigen pathway. Immunal. Today 10:229.

49 Szakal, A. K., Kosco, M. H., and Tew, J. G. 1989. Microanatomy of lymphoid tissue during humoral immune responses: structure function relationships. Annu. Rev. Immund. 7:91. 